\title{
A thermo-kinetic model base study on natural gas HCCI engine response to different initial conditions
}

\begin{abstract}
Homogenous Charge Compression Ignition (HCCI) combustion is a promising concept to reduce engine emmisions and fuel consumption. In this paper, a thermo-kinetic single zone model is developed to study the operation characteristics of a natural gas HCCI engine. The model consists detail chemical kinetics of natural gas oxidation including 325 reactions with 53 chemical species, and is validated with experimental results of reference works. Then, the influence of parameters such as manifold temperature/pressure, and equivalance ratio on incylinder temperature/pressure trends, start of combustion and heat release rate is studied. These results are explained in detail to describe the engine performance thoroughly.
\end{abstract}

Key words: HCCI, thermo-kinetic modeling, natural gas

\section{Termokinetyczny model silnika HCCI zasilanego gazem ziemnym wykorzystujący różne warunki początkowe}

\begin{abstract}
Zaleta silników wysokoprężnych o spalaniu homogenicznym (HCCI) jest możliwość zmniejszenia emisji związków toksycznych i zużycia paliwa. W artykule przedstawiono termokinetyczny jednostrefowy model silnika HCCI zasilanego gazem ziemnym. Model zawiera 325 reakcji chemicznych utleniania i jest skorelowany z wynikami doświadczalnymi uzyskanymi w innych badaniach. Przeanalizowano wplyw na prace silnika takich parametrów, jak: temperatura i ciśnienie dolotu, współczynnik nadmiaru powietrza w cylindrze, zmiana temperatury i ciśnienia w cylindrze oraz poczatek zapłonu $i$ szybkość wywiązywania się ciepła. Opisano rezultaty doświadczeń i ich wpływ na pracę silnika.
\end{abstract}

Słowa kluczowe: HCCI, modelowanie termokinetyczne, gaz ziemny

\section{Introduction}

The main concept of Homogenous Charge Compression Ignition (HCCI) engines was firstly represented by Onishi et al. [1] in 1979 for two stroke engines. They figured out that compressing a homogenous fuel/air mixture up to autoignition limit, would significantly reduce engine emissions and fuel consumption. This idea was named as Active Thermo-Atmospheric Combustion (ATAC) and rapidly developed by Noguchi et al [2]. They showed the advantages of this idea for part-load conditions. Najt et al [3] used this concept in four stroke engines and finally in 1989 Thring [4] named it as HCCI. The HCCI combustion process essentially involves a premixed fuel/air mixture that is inducted into the cylinder at equivalence ratios that can vary from 0.2 to 0.5 [5]. Once within the cylinder, the homogenous fuel/air charge is compressed until ignition commences. Ignition leads to a very rapid combustion phase were all heat is released approximately in $5-15^{\circ}$. This rate of heat release is controlled with a highly diluted mixtures using air or exhaust gas residual (EGR). The HCCI concept affords the use of elevated compression ratios (approximately 17-20:1), unlike in SI engines, which are susceptible to knock. The combination of lean burning and high expansion ratios contributes to high thermal efficiencies that can approach $45 \%$ [6]. HCCI engines have demonstrated very low emissions of oxides of nitrogen $\left(\mathrm{NO}_{\mathrm{x}}\right)$ and particulate matter (PM), as well as high thermal efficiency at part load.

\section{Wprowadzenie}

Główne założenia koncepcji silników HCCI (Homogenous Charge Compression Ignition) dla silników dwusuwowych zaprezentowano w 1979 r. w pracy Onishiego i in. [1]. Opisano w niej ograniczenia stosowania tej metody, jednocześnie zwrócono uwagę na możliwość redukcji emisji związków szkodliwych i zmniejszenia zużycia paliwa. Ideę tę nazwano aktywnym termicznym spalaniem ATAC (Active Thermo-Atmospheric Combustion) i rozwinięto ją w pracach Noguchiego i in. [2]. Przedstawili oni zalety takiego rozwiązania dla częściowych obciążeń silnika. Rozwiązania tego użył Najt [3] w 1989 r. w odniesieniu do silników czterosuwowych, a Thring [4] nazwał je HCCI. Proces spalania HCCI wykorzystuje wstępnie wymieszane paliwo z powietrzem - mieszanina ta jest wprowadzona do cylindra w proporcji mogącej się zmieniać od 0,2 do 0,5 [5]. W cylindrze homogeniczna mieszanina paliwa i powietrza jest sprężana aż do chwili zapłonu. Zapłon prowadzi do bardzo szybkiej fazy spalania, która trwa w przybliżeniu 5-15 $5^{\circ}$ OWK. Szybkość wywiązywania się ciepła jest sterowana głównie przez rozcieńczenie paliwa powietrzem lub przez stopień recyrkulacji spalin. W silnikach HCCI można wykorzystywać duże stopnie sprężania (około 17-20), w przeciwieństwie do silników o ZI, które są podatne na spalanie stukowe. Połączenie mieszanek ubogich i dużych stopni rozprężania przyczynia się do uzyskania wysokich wartości sprawności cieplnej, wynoszącej 45\% [6]. Silniki HCCI 
However, there are some difficulties in applying HCCI combustion to internal combustion engines. Ignition timing control and homogenous mixture preparation are the main difficulties of HCCI engines [7].

Natural gas fuel exhibits minimal mixture preparation requirements, and is chemically very stable. It is well suited to the HCCI combustion concept. Natural gas exhibits a relatively simple molecular structure, which reacts to yield far less intermediate compounds as well as a low carbon to hydrogen ratio (1:3.87) that results in reduced harmful exhaust gas emissions. Its high ignition resistance when coupled with lean fuel/air mixtures affords the use of elevated compression ratios without pre-ignition of the charge [6].

Engine simulation studies have been used to explore the HCCI concept in an engine environment. The simulation can be held under several methods which are described and compared in [8]. Each method of HCCI engine simulation has its own advantages/disadvantages and is selected by the requirements of the user. Hosseini et al [9] used a singlezone model with detailed chemical kinetics to control the combustion phenomena in an HCCI engine fueled with nheptane. Shahangian et al [10] also used the same model to investigate the characteristics of a DME-fueled HCCI engine. Orlandini et al [11] developed a multi-zone model with reduced chemical kinetics by linking MATLAB ${ }^{\circledR}$ environment to $\mathrm{CHEMKIN}^{\circledR}$ code in order to study the auto-ignition of HCCI engines. Numerical studies of Grenda [11] on charge stratification for the combustion control of HCCI engines were carried out by a CFD model. Gharabaghi et all [13] used the RICARDO ${ }^{\circledR} 1$-D code to investigate a turbocharged HCCI engine. Kongsereeparp and Checkel [14] also presented their new approaches to define the initial conditions for multi-zone HCCI models.

This paper introduces a zero-dimensional single zone model considering detailed chemical kinetics in order to study on the operational and combustion characteristics of a natural gas HCCI engine. High computational speed, appropriate precision for calculating parameters such as start of combustion (SOC) and in cylinder temperature/pressure trends are the main reasons of using this model. In the next chapter, the developed model is described. This model is validated with experimental results of the references. The final chapters include the results on engine performance and combustion characteristics.

\section{Thermo-Kinetic Modeling of HCCI engine}

As mentioned before, a zero-dimensional single zone model is developed in this paper to study the characteristics of a natural gas HCCI engine. The model assumptions can be described as below:

- the engine is a four-stroke HCCI one

- only the closed cycle form IVC to EVO is mentioned in the model

- the whole combustion chamber is defined as a uniform temperature/pressure zone

- all the components in the combustion chamber are treated as perfect gas charakteryzują się bardzo niewielką emisją tlenków $\left(\mathrm{NO}_{\mathrm{x}}\right) \mathrm{i}$ cząstek stałych (PM), a jednocześnie wysoką sprawnością na obciążeniach częściowych. Jednakże występują trudności w zastosowaniu systemu HCCI w silnikach spalinowych. Sterowanie czasem spalania i homogenicznym przygotowaniem mieszaniny są głównymi trudnościami w działaniu silników wykorzystujących system spalania HCCI [7].

Gaz ziemny jako paliwo charakteryzuje się bardzo małymi wymaganiami odnośnie do przygotowania mieszaniny palnej, a jednocześnie jest chemicznie niezmienny. Jest bardzo dobrym paliwem do silników HCCI. Gaz ziemny ma prostą budowę cząsteczkową. Jednocześnie mały stosunek węgla do wodoru $(1: 3,87)$ sprawia, że uzyskuje się zmniejszenie emisji związków szkodliwych spalin. Jego duża odporność na spalanie stukowe podczas spalania mieszanek ubogich pozwala na stosowanie wysokich stopni sprężania bez obawy przedwczesnego zapłonu [6].

Badania silnika wykorzystującego system HCCI przeprowadzono w celu zweryfikowania jego oddziaływania na środowisko. Badania symulacyjne prowadzono kilkoma metodami, które opisano i porównano w [8]. Każda metoda symulacji silnika HCCI jest obarczona korzyściami lub wadami i może być dowolnie wybrana przez użytkownika.

Hosseini i in. [9] użyli jednostrefowego modelu z równaniami reakcji chemicznych do opisu zjawiska zapłonu w silniku HCCI zasilanego n-heptanem. Shahangian i in. [10] użyli tego samego modelu - zmiana polegała na zastosowaniu innego paliwa - DME. Orlandini i in. [11] rozwinęli wielostrefowy model do symulowania samozapłonu w silniku HCCI ze zredukowanymi reakcjami chemicznymi przez połączenie środowiska MATLAB ${ }^{\circledR}$ ze środowiskiem CHEMKIN $^{\circledR}$. Symulacje numeryczne prowadzone przez Grenda [11] dotyczące stratyfikacji ładunku w silniku HCCI wykorzystywały model CFD. Gharabaghi i in. [13] wykorzystywali model RICARDO ${ }^{\circledR} 1$-D do badania turbodoładowanego silnika HCCI. Kongsereeparp i Checkel [14] prezentowali nowe rozwiązanie do definiowania warunków początkowych dla wielostrefowego modelu silnika HCCI.

$\mathrm{W}$ artykule przedstawiono zerowymiarowy jednostrefowy model wykorzystujący reakcje chemiczne w celu scharakteryzowania spalania w silniku HCCI zasilanego gazem ziemnym. Znaczna szybkość i dokładność w obliczaniu parametrów, m.in. początku zapłonu (SOC), temperatury i ciśnienia w cylindrze są głównymi powodami wykorzystywania tego modelu. Model będzie dokładnie opisany w następnym rozdziale. Zweryfikowano go doświadczalnie - w ostatnim rozdziale zawarto wyniki uzyskanych parametrów operacyjnych i charakterystyk procesu spalania.

\section{Termokinetyczny model silnika HCCI}

Wspomniany zerowymiarowy jednostrefowy model, prezentowany w artykule, wykorzystano do badania silnika HCCI zasilanego gazem ziemnym. Model wymagał następujących założeń wstępnych:

- czterosuwowy silnik HCCI

- rozpatrywany jest zamknięty cykl: od zamknięcia zaworu dolotowego do otwarcia zaworu wylotowego 
- blow-by is neglected

- the fuel/air mixture in IVC is completely homogenous

- the heat transfer to cylinder wall is calculated by Woschni model.

For exact study on combustion phenomena, detail chemical kinetics has been considered in the model. The GRI30 [15] mechanism used in this paper includes 325 primary reactions with 53 chemical species. As this mechanism covers the reactions of methane, ethane and propane oxidation and also the extended Zeldovich mechanism to calculate $\mathrm{NO}_{x}$ emissions, it is suitable for investigation on natural gas combustion.

\section{Governing the equations}

In a zero-dimensional model, the whole combustion chamber is considered as the control volume. Then, the energy conservation equation is solved for this zone. Figure 1 shows the terms of energy conservation equation in this system.

The energy conservation equation can be described as,

$$
\delta \mathrm{Q}-\delta \mathrm{W}=\mathrm{dU}
$$

Equation (1) can rewritten for the mixture of several chemical species as,

$$
\delta Q-P d V=m d u+m \sum_{i=1}^{N_{s}} u_{i} d y_{i}
$$

As $Q$ is only due to heat transfer to cylinder wall and the mixture is a perfect gas,

$$
\frac{d q}{d t}-P \frac{d V}{d t}=m C_{v} \frac{d T}{d t}+m \sum_{i=1}^{N_{s}} u_{i} \frac{d y_{i}}{d t}
$$

By separating the temperature terms, the first differential equation of the model can be obtained,

$$
\frac{\mathrm{dT}}{\mathrm{dt}}=\frac{\frac{1}{\mathrm{~V}}\left(\frac{\mathrm{dq}}{\mathrm{dt}}-\mathrm{P} \frac{\mathrm{dV}}{\mathrm{dt}}\right)-\rho \sum_{\mathrm{i}=1}^{\mathrm{N}_{\mathrm{s}}} \mathrm{u}_{\mathrm{i}} \frac{\mathrm{dy_{i }}}{\mathrm{dt}}}{\rho \mathrm{C}_{\mathrm{v}}}
$$

This equation describes that the in cylinder temperature changes, originate from two sources:

- energy transfer through system border

- changes in system chemical composition

The mass conservation equation is the next frame that should be considered after the energy conservation. The mass conservation equation in chemical reacting systems is defined as the conservation of chemical elements. The rate of mole fraction changes of chemical species can be computed as,

$$
\frac{\mathrm{dy}_{\mathrm{i}}}{\mathrm{dt}}=\frac{\mathrm{M}_{\mathrm{i}} \dot{\omega}_{\mathrm{i}}}{\rho}
$$

Equation (5) should be written for every chemical component and these set of equations must be solved simultaneously with equation (4). A detailed chemical kinetic mechanism is
- w całej objętości zapłonu zdefiniowana jest jednolita temperatura i ciśnienie

- czynnikiem roboczym jest gaz doskonały

- brak przedmuchów

- mieszanina paliwowo-powietrzna od chwili zamknięcia zaworu dolotowego jest homogeniczna

- wymiana ciepła ze ściankami cylindra odbywa się z wykorzystaniem modelu Woschniego.

W celu dokładnego zbadania procesu spalania, w modelu rozważono kinetykę reakcji chemicznych. Model GRI30 [15] użyty w badaniach zawiera 325 najważniejszych reakcji z 53 specjalności chemicznych. Ponieważ mechanizm ten wykorzystuje przemiany metanu, etanu oraz utleniania propanu do obliczeń emisji tlenków azotu użyto rozszerzonego modelu Zeldowicza.

\section{Opis równań}

W zerowymiarowym modelu cała komora spalania jest rozważana jako jednorodna objętość. Wtedy równanie zachowania energii jest rozwiązywane dla tej strefy. Na rysunku 1 przedstawiono warunki równania zachowania energii $\mathrm{w}$ rozpatrywanym systemie.

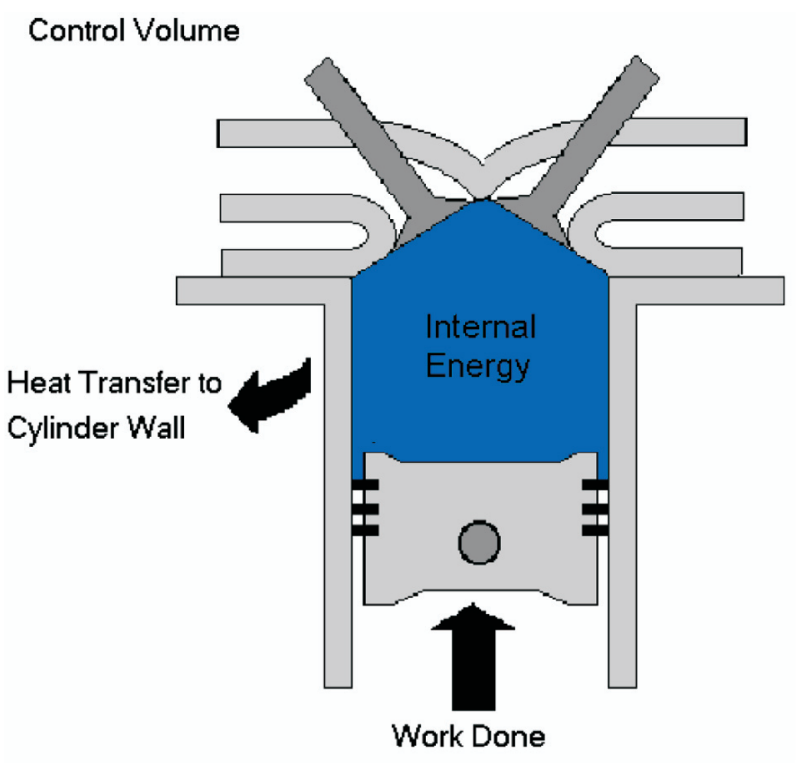

Fig. 1.Control volume in a zero-dimensional single zone model Rys. 1. Rozpatrywana objętość w zerowymiarowym jednostrefowym modelu

Równanie zachowania energii jest zapisane jako (1).

Równanie (1) może być zapisane dla mieszaniny substratów jako (2).

Ponieważ Q jest ciepłem przekazywanym do ścianek cylindra i mieszanina jest gazem doskonałym, zatem można zapisać (3).

Pierwsze równanie różniczkowe otrzymano po rozdzieleniu zmiennych zależnych od temperatury - równanie (4). Równanie to opisuje zmianę temperatury spowodowaną przez:

- przepływ energii

- zmianę składu chemicznego. 
needed to determine the production/consumption rate of each chemical component. A primary reaction in the mechanism can be written as,

$$
\mathrm{aA}+\mathrm{bB} \underset{\leftarrow}{\rightarrow} \mathrm{cC}
$$

The Mass Action rule explains that the reaction rate in each direction depends on that side reactants' concentration and their stoichiometric coefficients. So the reaction rate in the forward direction is,

$$
\mathrm{RR}_{\mathrm{f}}=\mathrm{k}_{\mathrm{f}}[\mathrm{A}]^{\mathrm{a}}[\mathrm{B}]^{\mathrm{b}}
$$

And for the backward direction,

$$
\mathrm{RR}_{\mathrm{b}}=\mathrm{k}_{\mathrm{b}}[\mathrm{C}]^{\mathrm{c}}
$$

So the total reaction rate can be defined as,

$$
\mathrm{RR}=\mathrm{k}_{\mathrm{f}}[\mathrm{A}]^{\mathrm{a}}[\mathrm{B}]^{\mathrm{b}}-\mathrm{k}_{\mathrm{b}}[\mathrm{C}]^{\mathrm{c}}
$$

Symbol $[\mathrm{A}]$ means the molar concentration of the component $\mathrm{A}$, and the rate constant $\mathrm{k}$ would be determined by Arrhenius relation [16],

$$
k=A_{A r} T^{\beta} \exp \left(\frac{-E_{a}}{R_{u} T}\right)
$$

Each mechanism consists some primary reactions which are either simple or with third body. A simple primary reaction can be assumed as,

$$
\sum_{k=1}^{N_{s}} v^{\prime}, i, S_{i \leftarrow} \rightarrow \sum_{k=1}^{N_{s}} v^{\prime \prime}{ }_{k, i} S_{i} \quad i=1,2, \ldots, N_{R}
$$

For each simple primary reaction, the reaction rate equation turns to,

$$
\mathrm{RR}_{\mathrm{i}}=\mathrm{k}_{\mathrm{f}, \mathrm{i}} \prod_{\mathrm{k}=1}^{\mathrm{Ns}}\left[\mathrm{S}_{\mathrm{k}}\right]^{\mathrm{u}_{\mathrm{k}, \mathrm{i}}^{\prime}}-\mathrm{k}_{\mathrm{b}, \mathrm{i}} \prod_{\mathrm{k}=1}^{\mathrm{Ns}}\left[\mathrm{S}_{\mathrm{k}}\right]^{\mathrm{v}_{\mathrm{k}, \mathrm{i}}}
$$

Some primary reactions need a third body to be done. As the concentration of the third body would effect the reaction rate, it differs from equation (12) and should be written as,

$$
\sum_{\mathrm{k}=1}^{\mathrm{N}_{\mathrm{s}}} \mathrm{v}_{\mathrm{k}, \mathrm{i}} \mathrm{S}_{\mathrm{i}}+\mathrm{TB}_{\leftarrow} \rightarrow \sum_{\mathrm{k}=1}^{\mathrm{N}_{\mathrm{s}}} \mathrm{v}_{\mathrm{k}_{\mathrm{j}} \mathrm{i}} \mathrm{S}_{\mathrm{i}}+\mathrm{TB}
$$

The third body concentration includes the concentrations of all species due to their enhance factor. So the reaction rate for these type of primary reactions is,

$$
\begin{aligned}
\operatorname{RR}_{\mathrm{i}}= & \left(\sum_{\mathrm{k}=1}^{\mathrm{N}_{\mathrm{s}}} \mathrm{a}_{\mathrm{k}, \mathrm{i}}\left[\mathrm{TB}_{\mathrm{k}}\right]\right) \times \\
& \left(\mathrm{k}_{\mathrm{f}, \mathrm{i}} \prod_{\mathrm{k}=\mathrm{l}}^{\mathrm{N}_{\mathrm{s}}}\left[\mathrm{S}_{\mathrm{k}}\right]^{\mathrm{u}_{\mathrm{k}, \mathrm{i}}}-\mathrm{k}_{\mathrm{b}, \mathrm{i}} \prod_{\mathrm{k}=\mathrm{l}}^{\mathrm{N}_{\mathrm{s}}}\left[\mathrm{S}_{\mathrm{k}}\right]^{\mathrm{v}^{\prime \prime}, \mathrm{i}}\right)
\end{aligned}
$$

Równanie zachowania masy jest następnym równaniem mogącym mieć zastosowanie po równaniu zachowania energii. Równanie zachowania masy reagujących substancji chemicznych jest zdefiniowane jako równanie sumy zachowania masy poszczególnych jej reagentów. Szybkość zmiany udziału substancji chemicznej może być obliczona jako (5).

Równanie (5) powinno być zapisane dla każdego składnika osobno i rozwiązane równocześnie z równaniem (4).

Do określenia szybkości produkcji/zużywania poszczególnych składników wymagana jest znajomość kinetyki reakcji chemicznych. Ogólny mechanizm reakcji może być zapisany jako (6).

Reguła mechanizmu masowego mówi, że szybkość reakcji w każdym kierunku zależy od stężenia reagentów i stałych szybkości reakcji. Szybkość reakcji „do przodu” opisana jest wzorem (7), a szybkość reakcji „do tyłu”-(8). Reakcja wynikowa jest zdefiniowana jako (9).

Symbol [A] oznacza udział molowy składnika A, a stała szybkości reakcji k określona jest wzorem Arrheniusa [16] (10).

Każdy mechanizm składa się z głównych reakcji, które albo są jawne, albo wymagają składników dodatkowych ${ }^{1)}$ (TB - third body). Główna reakcja może zostać zapisana jako (11).

Dla każdej głównej reakcji, równanie szybkości reakcji opisane jest wzorem (12).

Niektóre główne reakcje wymagają obliczenia dodatkowego składnika TB. Ponieważ obliczenie jego wymaga znajomości szybkości reakcji, różni się więc od równania (12) i powinno być napisane jako (13).

Stężenie TB zawiera więc stężenia wszystkich wchodzących w jego skład czynników. W związku z tym szybkość głównej reakcji można zapisać jako (14).

Współczynniki mogą być obliczone według różnych źródeł, np. wielomianów NASA [17]. W związku z tym szybkość produkcji/zużycia każdego składnika chemicznego może być obliczona jako (15).

Do całościowego rozwiązania zagadnienia potrzebne jest jeszcze jedno równanie - oprócz znanych już równań różniczkowych zmiany temperatury i masy - jest nim równanie (16), opisujące szybkość zmian objętości komory spalania i wywodzi się ono z klasycznej teorii silników spalinowych [18].

Zdefiniowanie dq/dt zwykle wymaga przyjęcia modelu wymiany ciepła Woschniego, ale dzięki znacznej szybkości spalania w silnikach HCCI, w badaniach użyto zmodyfikowanej zależności, określonej w [19]. Zmodyfikowany model opisany jest zależnością (17), gdzie współczynnik przewodzenia ciepła jest zdefiniowany jako (18).

\section{Weryfikacja modelu}

Dane doświadczalne posłużyły do weryfikacji zaproponowanego w artykule zerowymiarowego jednostrefowego

1) Składnik reakcji, który nie bierze bezpośredniego udziału w wymianie molekularnej, ale doprowadza do osiągnięcia poziomu energetycznego cząsteczki poddawanej procesowi molekularnemu lub do reakcji kombinowanej pomiędzy atomami lub rodnikami (przyp. tłum.). 
The coefficients can be obtained from different sources like NASA polynomials [17]. So the production/consumption rate of each chemical component can be calculated as,

$$
\dot{\omega}_{k}=\sum_{k=1}^{N_{R}} R_{i}\left(v_{k, i}^{\prime}-v_{k, i}^{\prime \prime}\right)
$$

Now, we need another differential equation beside temperature and species masses to enclose our differential equations system. This equation defines the rate of changes in combustion chamber and would be found in classic engine texts [18] as below,

$$
\mathrm{V}=\mathrm{V}_{\mathrm{c}}\left(1+\frac{\mathrm{r}_{\mathrm{c}}-1}{2}\left(\mathrm{R}+1-\cos \theta-\sqrt{\mathrm{R}^{2}-\sin ^{2} \theta}\right)\right)
$$

For defining dq/dt, we usually use Woschni heat transfer model but due to rapid combustion period of HCCI engines, a modified relation [19] has been used in this paper. This modified model describes,

$$
\frac{\mathrm{dq}}{\mathrm{dt}}=\mathrm{hA}\left(\mathrm{T}-\mathrm{T}_{\mathrm{w}}\right)
$$

Where the convection heat transfer coefficient is,

$$
\begin{aligned}
& \mathrm{h}=129.8 \mathrm{~B}^{-0.2} \mathrm{P}^{0.8} \mathrm{~T}^{-0.55}\left(2.25 \mathrm{~S}_{\mathrm{p}}+\mathrm{f}(\mathrm{P})\right)^{0.8} \\
& \mathrm{f}(\mathrm{p})=3.34 \times 10^{-4} \frac{\mathrm{V}_{\mathrm{d}} \mathrm{T}_{\mathrm{r}}}{\mathrm{P}_{\mathrm{r}} \mathrm{V}_{\mathrm{r}}}\left(\mathrm{P}-\mathrm{P}_{\text {mot }}\right)
\end{aligned}
$$

\section{Model Validation}

Experimental data from referenced works has been used to validate the developed zerodimensional single zone model. Two engines with different geometry and operational conditions have been tested to ensure the model accuracy. The engines' geometry is shown in table 1 , and table 2 indicates the engines' operational conditions.

Figure 2 shows the pressure trend in engine no.1. The experimental results are derived from reference [6].

As shown in figure 2, the model can predict the operational conditions of an HCCI engine with appropriate accuracy. Figures 3 and 4 which are the model results for engine no. 2 and compared with experimental data in reference [20] also show the same accuracy. Similar to all zero dimensional models, the pick cylinder pressure/temperature is higher that the experimental results, and also occur earlier. This is because of:

- The homogeneity of combustion chamber is the main assumption of single zone models. But in real cases, there are some in-homogeneities in air/fuel mixture at IVC and also during the engine strokes, the near-wall areas has lower temperature because of heat transfer to cylinder wall.

- HCCI combustion occurs in short period, low temperature and high pressure. So, a fraction of fuel enters the crevices and do not ignite. As the single zone models neglect the crevices, there would be a difference between model and real operation. modelu. Do weryfikacji wykorzystano dwa silniki o różnych wymiarach geometrycznych i parametrach eksploatacyjnych. Wymiary geometryczne zaprezentowano w tab. 1, a w tab. 2 zamieszczono podstawowe parametry operacyjne.

Table 1. Geometry of tested engines

Tabela 1. Parametry geometryczne silników użytych do weryfikacji

\begin{tabular}{|l|c|c|}
\hline & Engine No. 1 & Engine No. 2 \\
\hline Name/nazwa & Volvo TD 100 & Caterpillar 3500 \\
\hline Bore/średnia $[\mathrm{mm}]$ & 120.65 & 170 \\
\hline Stroke/skok $[\mathrm{mm}]$ & 140 & 190 \\
\hline $\begin{array}{l}\text { Rod length/dtugość } \\
\text { korbowodu }[\mathrm{mm}]\end{array}$ & 260 & 350 \\
\hline $\begin{array}{l}\text { Compression ratio/ } \\
\text { stopié́ sprężania }\end{array}$ & 19.8 & 17 \\
\hline IVC (ABDC) & 13 & 20 \\
\hline EVO (BBDC) & 39 & 40 \\
\hline $\begin{array}{l}\text { Speed/prędkość } \\
\text { obrotowa }[\mathrm{rpm}]\end{array}$ & 1000 & 1500 \\
\hline
\end{tabular}

Table 2. Operational conditions of tested engines Tabela 2. Parametry operacyjne badanych silników

\begin{tabular}{|l|c|c|}
\hline & Engine No.1 & Engine No.2 \\
\hline $\begin{array}{l}\text { Inlet manifold pressure/ciśnie- } \\
\text { nie } \text { w kolektorze dolotowym } \\
{[\text { bar] }}\end{array}$ & 1 & 2 \\
\hline $\begin{array}{l}\text { Equivalence ratio/współczynnik } \\
\text { równoważności }\end{array}$ & 0.3 & 0.3 \\
\hline $\begin{array}{l}\text { Cylinder wall temperature/tem- } \\
\text { peratura ścianek cylindra }[\mathrm{K}]\end{array}$ & 400 & 375 \\
\hline \begin{tabular}{l} 
Fuel/paliwo \\
\hline
\end{tabular} & $\begin{array}{l}99 \% \text { Methane } \\
+1 \% \text { Propane }\end{array}$ & $100 \%$ Methane \\
\hline
\end{tabular}

Na rysunku 2 pokazano zmiany ciśnienia w cylindrze dla silnika opisanego numerem 1. Wyniki doświadczalne zaczerpnięto z pozycji [6].

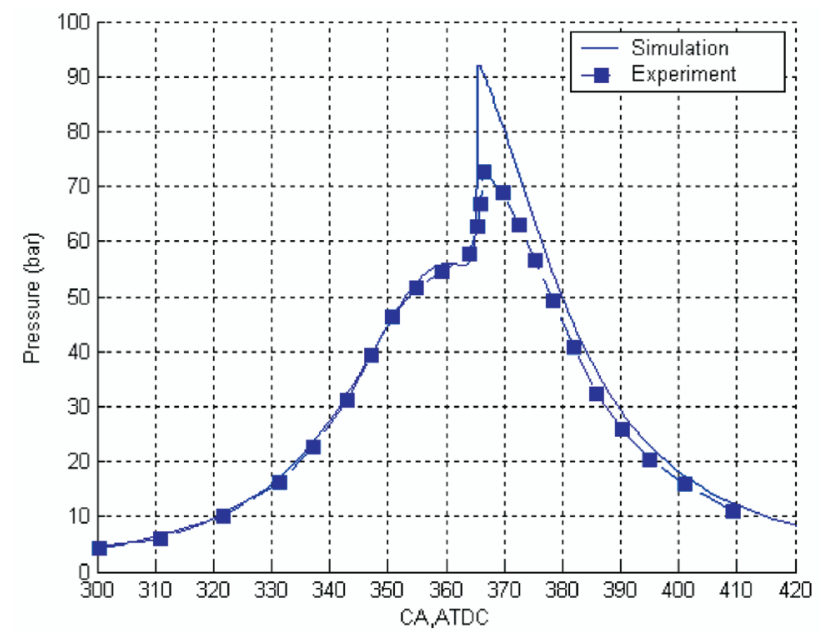

Fig. 2. Pressure trend versus crank angle in engine no. 1 Rys. 2. Zmiana ciśnienia w cylindrze jako funkcja kąta obrotu watu korbowego (silnik nr 1) 
Single zone models are widely used because of their high calculation speed, exact prediction of SOC and accurate determination of $\mathrm{NO}_{\mathrm{x}}[6,8,10$ and 20]. For comparison studies, the relative changes are significant so the global inaccuracy of the model could be neglected and the zero-dimensional single zone models are well suited for this purpose [21]. So due to the target of this paper, the developed model can be used without any problems.

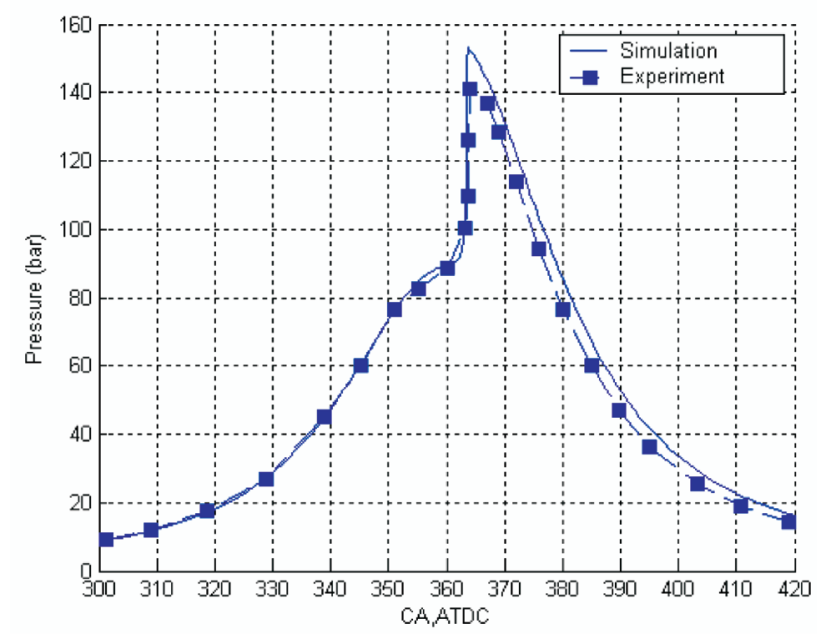

Fig. 3. Pressure trend versus crank angle in engine no. 2

Rys. 3. Zmiana ciśnienia w cylindrze jako funkcja kąta obrotu wału korbowego (silnik nr 2)

\section{Results and discussions}

The developed code has been run several times to investigate the influence of different parameters on operational characteristics of an HCCI engine. At first, the influence of inlet air/fuel temperature has been studied. This work was done for engine no. 1 with 1 bar initial pressure, 0.3 equivalence ratio and $99 \%$ methane $+1 \%$ propane fuel. The initial temperature was changed form $400 \mathrm{~K}$ to $600 \mathrm{~K}$ in 4 steps. The results are shown in figure 5 . The primary reaction rates will increase when the initial temperature is higher so the combustion occurs earlier. But it should be mentioned that the increased initial temperature will decrease volume and thermal efficiency and also the amount of entering fuel. So it will lead to decreasing output power.

The best SOC timing depends on several parameters but totally the best time is just before TDC. Figure 6 shows the influence of a more limited range of initial temperature on SOC. The conditions are like figure (3) but the temperature changes from $380 \mathrm{~K}$ to $470 \mathrm{~K}$ in 7 steps.

At initial temperature of $380 \mathrm{~K}$, the combustion did not occur, but increasing the temperature to $395 \mathrm{~K}$ would start the combustion. In this case, SOC occurs after TDC. SOC occur 3-5 CAD earlier with every $15 \mathrm{~K}$ increase in initial temperature. Although the best SOC depends on several parameters but in this special case, we can conclude that the best initial temperature is $410 \mathrm{~K}$ because SOC occurs just before TDC and the maximum pressure is higher than other cases. The maximum value of in cylinder pressure directly increase the engine output power.
Na podstawie zaprezentowanego przebiegu zmian ciśnienia w cylindrze (rys. 2) zaproponowany model dobrze odzwierciedla parametry operacyjne silnika HCCI. Przebiegi zmiany ciśnienia (rys. 3) i temperatury (rys. 4) w cylindrze, które są wynikiem symulacji dla silnika $\mathrm{nr} 2$, porównano z doświadczalnymi danymi z [20]; ukazują one podobną dokładność do uzyskanej dla silnika nr 1. Podobne do wszystkich zerowymiarowych modeli uzyskane wartości ciśnienia

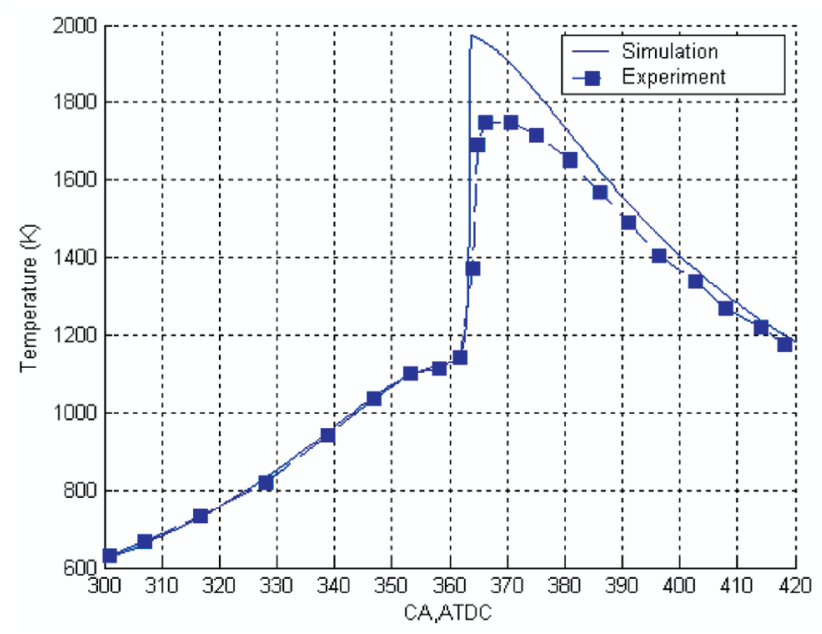

Fig. 4. Temperature trend versus crank angle in engine no. 2 Rys. 4. Zmiana temperatury w cylindrze jako funkcja kąta obrotu walu korbowego (silnik nr 2)

i temperatury w cylindrze są wyższe od doświadczalnych, a jednocześnie występują dla wcześniejszego położenia kątowego wału korbowego. Główne powody tego stanu, to:

- jednorodność składu mieszaniny w komorze spalania jest głównym założeniem jednostrefowego modelu; w rzeczywistych warunkach występuje niejednorodność składu powietrze/paliwo po zamknięciu zaworu dolotowego, jak również podczas ruchu tłoka, obszary przyścienne mają niższą temperaturę z powodu przepływu ciepła do ścianek cylindra;

- spalanie następuje szybko, w niskiej temperaturze i przy wysokim ciśnieniu; pod wpływem efektu szczelinowego nie jest zapalana niewielka ilość paliwa; ponieważ jednostrefowe modele nie uwzględniają tego efektu, występują różnice między modelem a rzeczywistą pracą silnika.

Jednowymiarowych modeli spalania używa się z powodu dużej szybkości obliczeń, precyzyjnego określania początku spalania oraz dokładnego szacowania emisji tlenków azotu [6, $8,10,20]$. Do celów porównawczych z powodzeniem mogą być stosowane zerowymiarowe modele jednostrefowe [21].

\section{Wyniki i ich analiza}

Wyniki badań sprawdzano kilkakrotnie w celu zbadania wpływu różnych parametrów na warunki pracy silnika HCCI. Pierwszym badanym parametrem był wpływ temperatury mieszaniny powietrza na wlocie do silnika. Badania wykonano dla silnika nr $1 \mathrm{z}$ ciśnieniem początkowym wynoszącym 1 bar, stosunkiem paliwo-powietrze wynoszącym 0,3 oraz składem paliwa - 99\% metanu i $1 \%$ propanu. Temperatura początkowa była zmieniona od 


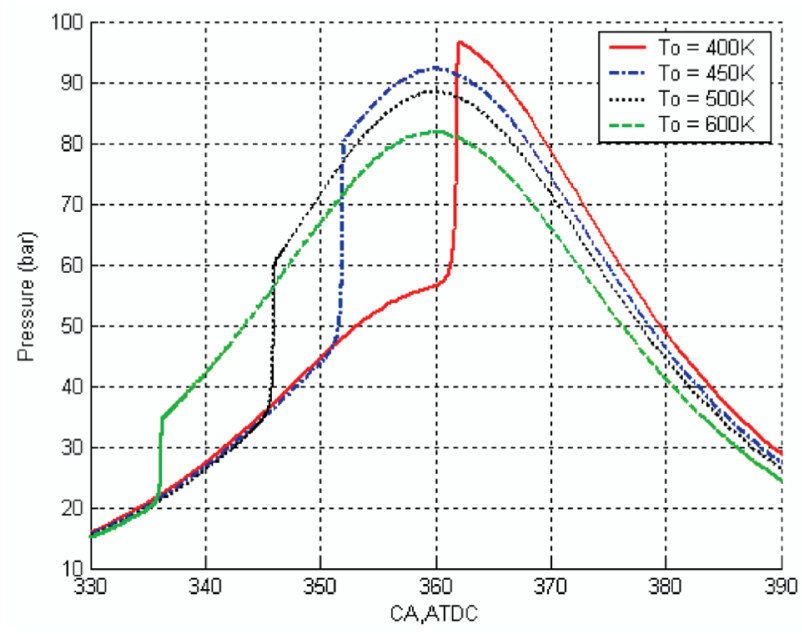

Fig. 5. The influence of initial temperature on pressure trend and SOC in engine no. 1

Rys. 5. Wpływ początkowej temperatury na wartość ciśnienia i początek spalania (silnik $n r$ 1)

Methane $\left(\mathrm{CH}_{4}\right)$ is the main component of natural gas. In general terms, low temperature oxidation of methane is initiated by the generation of hydroperoxy radical via reaction,

$$
\mathrm{CH}_{4}+\mathrm{O}_{2} \rightarrow \dot{\mathrm{C}} \mathrm{H}_{3}+\mathrm{HO}_{2}
$$

The hydroperoxy radical is stable at low temperatures but the methyl radical is quickly decomposed in a chain propagating reaction [22]. So the chemical progress is usually quantified with hydroperoxy radical generation, which is plotted in figure 7. This figure is plotted for two cases:

1) no combustion (initial temperature of $380 \mathrm{~K}$ )

2) combustion (initial temperature of $410 \mathrm{~K}$ )

In "combustion" case, the mole fraction of hydroperoxy radical increases immediately but the trend for "no combustion" case is so low and totally because of isentropic increase of temperature via volume change.

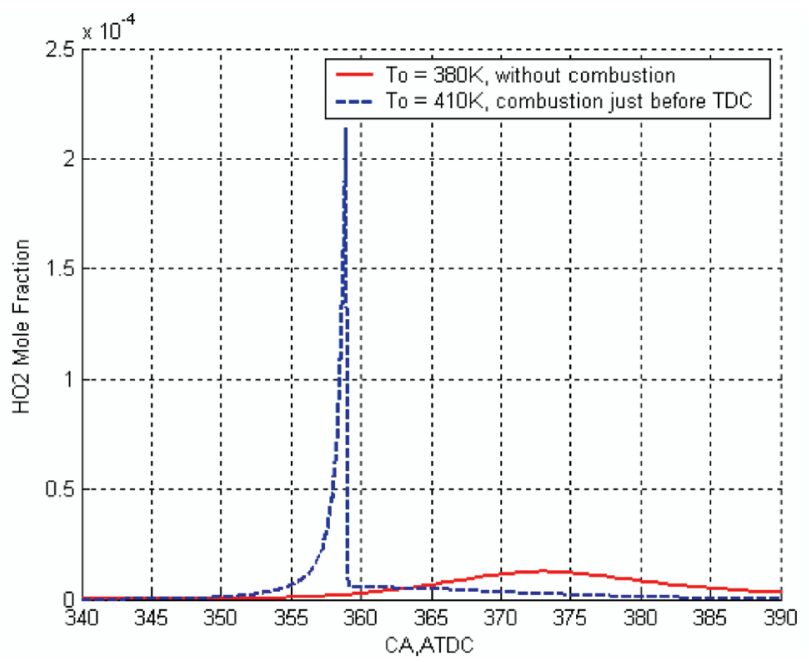

Fig. 7. Comparison between hydroperoxy mole fraction changes for combustion and no combustion cases in engine no. 1

Rys. 7. Porównanie udziału molowego uwodnionego rodnika dla przypadku ze spalaniem i bez spalania (silnik nr 1)

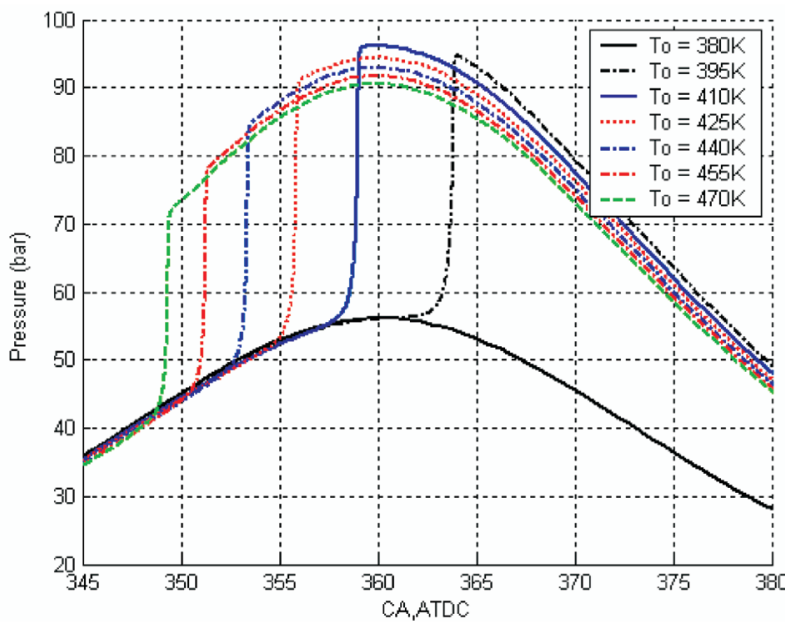

Fig. 6. The influence of limited range of initial temperature on maximum value of pressure and SOC in engine no. 1

Rys. 6. Wplyw poczatkowej temperatury na maksymalna wartość ciśnienia i początek spalania (silnik nr 1)

400 do $600 \mathrm{~K}$ w 4 punktach. Wyniki pomiarów pokazano na rys. 5. Szybkość reakcji zwiększa się wraz ze wzrostem temperatury, a jednocześnie wcześniej następuje samozapłon. Należy jednak zaznaczyć, że przy wzroście temperatury początkowej zmniejsza się objętość, maleje również współczynnik przejmowania ciepła i ilość doprowadzonego paliwa. Prowadzi to także do zmniejszania uzyskiwanej mocy.

Najlepszy początek spalania zależy od kilku parametrów, ale optymalny znajduje się tuż przed GMP. Na rysunku 6 pokazano wpływ początkowej temperatury na początek spalania. Warunki przeprowadzenia testu są podobne do tych $\mathrm{z}$ rys. 3 , lecz zmiany temperatury wykonano od 380 do $470 \mathrm{~K}$ w 7 punktach.

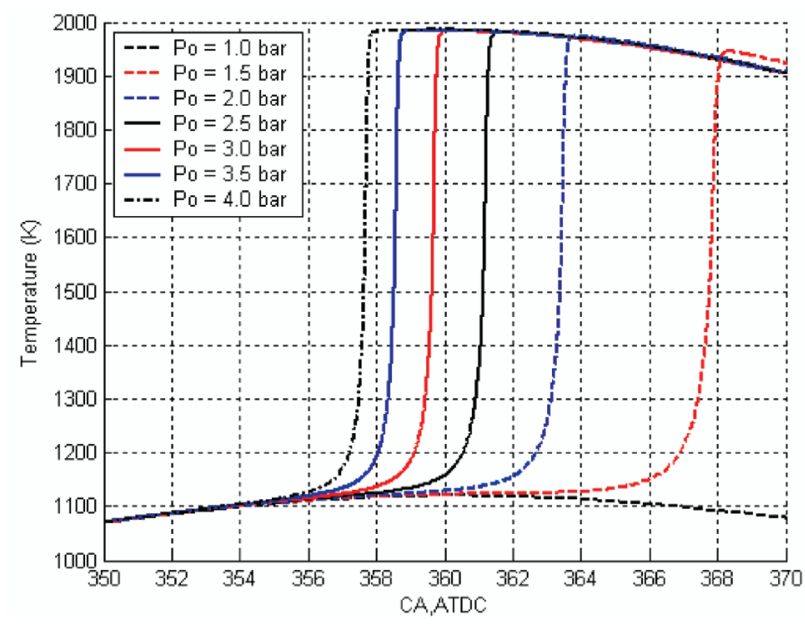

Fig. 8. The influence of initial pressure on temperature trend and SOC in engine no. 2

Rys. 8. Wplyw początkowego ciśnienia dolotu na zmiane temperatury w cylindrze (silnik $n r$ 2) 
The pressure of inlet air/fuel mixture is another effective parameter on HCCI engine operation. It could be adjusted by engine turbo-charging. Figure 8 shows the influence of intake pressure in SOC in engine no. 2 with initial temperature of $420 \mathrm{~K}$ and equivalence ratio of 0.3 . As shown in the figure, initial pressure of 1 bar do not lead to combustion and by increasing the intake pressure the combustion will appear. The most interesting fact is that, the initial pressure changes do not affect on the maximum value of the in cylinder temperature.

Totally, HCCI engines are lean-burn engines due to their combustion concept, for instance, equivalence ratio of natural gas HCCI engines is in the order of 0.3 . The influence of equivalence ratio is plotted in figure 9. This study has been done for engine no. 2 with initial temperature of $420 \mathrm{~K}$. In lower equivalence ratios, SOC occurs earlier but with lower temperature peak value. Increasing fuel concentration delays SOC but increase the maximum temperature/pressure. This increasing is good only for a limited range because extreme high temperature/pressure will lead to mechanical damages to engine. In higher equivalence ratios (eg. 0.7), the combustion do not occur because the temperature and pressure are not appropriate for auto ignition of this rich mixture.

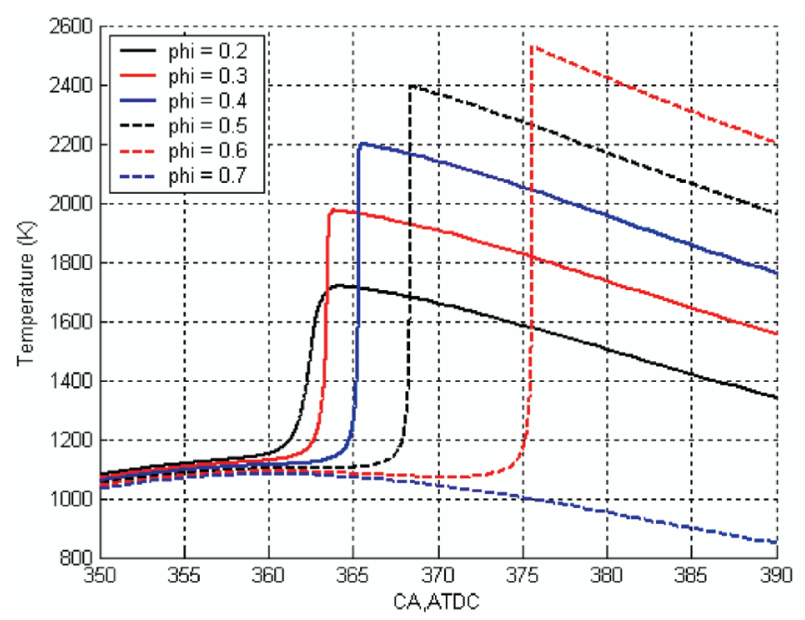

Fig. 9. The influence of equivalence ratio on temperature trend and SOC in engine no. 2

Rys. 9. Wplyw stosunku równoważności na wzrost temperatury i początek spalania (silnik $n \mathrm{r}$ 2)

\section{Conclusion}

The results of this study can be summarized as below: - zero-dimensional single zone model can predict SOC of HCCI engine with appropriate accuracy. Although it has a little error in defining some parameters but it is suitable for comparision studies

- the model developed in this paper can predict HCCI operational characteristics with appropriate accuracy

- initial temperature of inlet air/fuel mixture has an effective rule on combustion trend of HCCI engine. SOC will occue earlier with increasing initial temperature. When
W temperaturze początkowej $380 \mathrm{~K}$ zapłon nie nastąpił, ale wzrost temperatury do $395 \mathrm{~K}$ powoduje wystąpienie zapłonu. Wtedy początek spalania następuje po GMP. Początek spalania następuje 3-5 $5^{\circ} \mathrm{OWK}$ wcześniej przy zwiększaniu temperatury początkowej o każde $15 \mathrm{~K}$. Pomimo że optymalny początek spalania zależy od kilku parametrów, w przeprowadzonych badaniach określono, że najlepsza początkowa temperatura to $410 \mathrm{~K}$, gdyż początek spalania następuje tuż przed GMP, a uzyskiwane ciśnienie jest wyższe niż w innych przypadkach. Maksymalna wartość ciśnienia w cylindrze bezpośrednio zwiększa moc silnika.

Metan $\left(\mathrm{CH}_{4}\right)$ jest główną częścią składową gazu ziemnego. Ogólnie, niska temperatura utleniania metanu jest inicjowana zgodnie z reakcją (19).

Uwodniony rodnik jest stały w niskich temperaturach, lecz rodnik metylu szybko jest rozkładany w procesie rozpoczynającym reakcję [22]. Ten chemiczny proces jest zwykle związany z tworzeniem uwodnionych rodników (rys. 7). $\mathrm{Na}$ rysunku tym wyznaczono dwa przebiegi:

- bez spalania (początkowa temperatura $380 \mathrm{~K}$ )

- ze spalaniem (początkowa temperatura $410 \mathrm{~K}$ ).

Dla przypadku ,ze spalaniem”, udział molowy uwodnionego rodnika wzrasta bardzo gwałtownie, natomiast dla przebiegu „bez spalania” - udział molowy jest na niskim poziomie.

Ciśnienie dolotu mieszaniny powietrza i paliwa jest kolejnym efektywnym parametrem wpływającym na pracę silnika HCCI. Zależność ta mogłaby być wykorzystana do silników doładowanych. Na rysunku 8 przedstawiono wpływ ciśnienia dolotu na początek spalania dla silnika nr 2 z początkową temperaturą $420 \mathrm{~K}$ i przy stosunku równoważności 0,3 (paliwo/powietrze). Przy ciśnieniu początkowym wynoszącym 1 bar spalanie nie występuje, zwiększenie ciśnienia dolotu powoduje zapoczątkowanie spalania. Interesujące jest, że zmiana ciśnienia dolotu nie powoduje zmiany maksymalnej temperatury występującej w cylindrze.

Silniki HCCI spalające ubogie mieszanki mogą być zasilane gazem ziemnym przy stosunku paliwa do powietrza wynoszącym 0,3. Wpływ zmian tej wartości ma maksymalną temperaturę spalania pokazano na rys. 9. Badania przeprowadzono dla silnika nr 2, z początkową temperaturą mieszanki wynoszącą 420 K. Przy małych stosunkach równoważności paliwa do powietrza, początek zapłonu następuje wcześniej, ale z niższą maksymalną temperaturą spalania. Zwiększając koncentrację paliwa, opóźnia się początek zapłonu, lecz zwiększa się maksymalna temperatura i ciśnienie spalania. Wzrost tych wartości można stosować w ograniczonym zakresie, nie dopuszczając do mechanicznego (lub cieplnego) uszkodzenia silnika. Dla dużych stosunków równoważności (powyżej 0,7 ) zapłon mieszaniny nie następuje, ponieważ nie ma warunków do jej samozapłonu.

\section{Wnioski}

Podsumowanie wyników badań:

- zerowymiarowy jednostrefowy model można wykorzystać do określenia początku spalania w silniku HCCI z wymaganą dokładnością; można jednocześnie wykorzystać ją do porównywania wybranych parametrów, 
SOC occurs before TDC, increasing initial temperature would lead to decreasing in peak value of in cylinder temperature

- rapid incresing of hydroperoxy $\left(\mathrm{HO}_{2}\right)$ is a quantitive device for predicting SOC

- SOC will occur earlier with increasing inlet pressure but there would no significant changes in temperature peak value near TDC

- the best opeartional conditions of HCCI engines happen in lean-burn cases

- the combustion process of a natural gas HCCI engine will disappear by increasing the equivalence ratio above a limited range.

Artykut recenzowany
- za pomocą modelu rozpatrywanego w artykule przewidywano z dużą dokładnością parametry pracy silnika

- początkowa temperatura dolotu mieszaniny powietrza i paliwa ma wpływ na spalanie w silniku HCCI; początek spalania występuje wcześniej w miarę zwiększania początkowej temperatury dolotu; gdy początek spalania występuje przed GMP, wzrost temperatury dolotu powoduje zmniejszanie maksymalnej temperatury spalania

- gwałtowny wzrost rodnika $\mathrm{HO}_{2}$ jest miernikiem wystąpienia początku spalania

- początek spalania występuje wcześniej w miarę zwiększania ciśnienia dolotu, ale nie wnosi żadnych zmian w maksymalnej temperaturze spalania

- najlepsze warunki pracy silników HCCI występują dla mieszanek ubogich

- spalanie w silniku HCCI zasilanym gazem ziemnym zanika przy zwiększaniu stosunku równoważności poza zakres zapalności mieszanki.

\section{Nomenclature/Oznaczenia}

A area/obszar

a enhance factor of third body/wspótczynnik wzostu TB

A arrhenius coefficient/wspótczynnik Arrheniusa

$\mathrm{B}$ bore/średnica

$\mathrm{C}_{\mathrm{v}}$ specific heat in constant volume/ciepło właściwe przy stałej objętości

$\mathrm{E}_{\mathrm{a}}$ activation energy/energia aktywacji

$\mathrm{h}$ convection heat transfer coefficient/konwekcyjny wspótczynnik przejmowania ciepta

i counter/licznik

$\mathrm{k}$ counter/licznik

$\mathrm{k}_{\mathrm{b}}$ backward reaction rate constant/stała szybkości reakcji "do tylu”

$\mathrm{k}_{\mathrm{f}}$ forward reaction rate constant/stała szybkości reakcji "do przodu"

$\mathrm{M}_{\mathrm{i}}$ molar weight of component $\mathrm{i} /$ masa molowa sktadnika $i$

$\mathrm{m}$ mass/masa

$\mathrm{N}_{\mathrm{R}}$ number of reactions/numer reakcji

$\mathrm{N}_{\mathrm{S}}$ number of species/numer sktadnika

$\mathrm{P}$ pressure/ciśnienie

$\mathrm{P}_{\mathrm{m}}$ motoring Pressure/ciśnienie sprężania

$\mathrm{P}_{\mathrm{r}}{ }_{\mathrm{m}}$ reference pressure at IVC/ciśnienie odniesienia przy zamknięciu zaworu dolotowego

Q heat/ciepto

q heat transfer to cylinder wall/ciepło przekazane do ścianek cylindra

$\mathrm{R}$ rod length/cranks radius ration/dtugość korbowodu

$\mathrm{R}_{u}$ universal gas constant/uniwersalna stała gazowa

$\mathrm{r}_{\mathrm{c}} \quad$ compression ratio/stopień sprężania

$\mathrm{RR}_{\mathrm{b}}$ backward reaction rate/szybkość reakcji "do tylu”

$\mathrm{RR}_{\mathrm{f}}$ forward reaction rate/szybkość reakcji "do przodu”

$\mathrm{RR}_{\mathrm{i}}$ rate of reaction $\mathrm{i} /$ szybkość $i$-tej reakcji

$\mathrm{S}_{\mathrm{i}} \quad$ component $\mathrm{i} /$ sktadnik $i$

$\mathrm{S}_{\mathrm{p}} \quad$ average piston speed/średnia prędkość ttoka

$\mathrm{T}$ temperature/temperatura
$\mathrm{T}_{\mathrm{r}}$ reference temperature at IVC/temperatura odniesienia przy zamknięciu zaworu dolotowego

$\mathrm{T}_{w}$ cylinder wall temperature/temperatura ścianki cylindra

TB third body/sktadnik dodatkowy

$\mathrm{U}$ internal energy/energia wewnętrzna

$\mathrm{u} \quad$ specific internal energy/jednostkowa energia wewnętrzna

$\mathrm{u}_{\mathrm{i}} \quad$ specific internal energy of component $\mathrm{i} /$ jednostkowa energia wewnętrzna składnika $i$

$\mathrm{V}$ volume/objętość

$\mathrm{V}$ c clearance volume/objętość komory spalania

$\mathrm{V}_{\mathrm{d}}^{\mathrm{c}}$ displacement volume/pojemność skokowa

$\mathrm{V}_{\mathrm{r}}$ reference volume at IVC/objętość odniesienia przy zamknięciu zaworu dolotowego

$\mathrm{V}_{\mathrm{i}, \mathrm{k}}^{\prime}$ stoichiometric coefficient of component $\mathrm{i}$ in forward direction of reaction $\mathrm{k} /$ stechiometryczny wspótczynnik składnika i dla reakcji $k$ "do przodu"

$\mathrm{V}^{\prime \prime}$, stoichiometric coefficient of component $\mathrm{i}$ in backward direction of reaction $\mathrm{k} /$ stechiometryczny wspótczynnik sktadnika i dla reakcji $k$ "do tytu"

W work/praca

$\mathrm{y}_{\mathrm{r}} \quad$ mole fraction of component $\mathrm{i} /$ udzial molowy sktadnika $i$

$\beta$ arrhenius coefficient/wspótczynnik Arrheniusa

$\theta$ cranck angle/kat obrotu watu korbowego

$\rho$ density/gęstość

$\omega_{i} \quad$ production(consumption) rate of component i/ szybkość produkcji (zużywania) składnika $i$

\section{Abbrevations/Skróty}

ABDC after bottom dead center/po dolnym martwym punkcie

ATAC Active Thermo-Atmospheric Combustion/aktywny zapton termiczny

ATDC after top dead center/po górnym martwym punkcie

BBDC before bottom dead center/przed dolnym martwym punktem

CA crank angle/stopień obrotu

CFD Computational Fluid Dynamics/komputerowa dynamika płynów 
DME di-methyl ether/eter dimetylowy

EGR exhaust gas residual/udział gazów spalinowych

EVO exhaust valve opening/otwarcie zaworu wylotowego

GRI Gas Research Institute/Instytut Badawczy Gazów

HCCI homogenous charge compression ignition/samoczynny zapłon ładunku homogenicznego
IVC inlet valve closing/zamknięcie zaworu dolotowego

$\mathrm{NO}_{\mathrm{x}}$ oxides of nitrogen/tlenki azotu

PM particulate matter/cząstki state

SI spark ignition/zapton iskrowy

SOC start of combustion/początek spalania

\section{Bibliography/Literatura}

[1] Onishi S., Hong Jo S., Shoda K., Kato S.: Active Thermo-Atmosphere Combustion (ATAC) - A New Combustion Process for Internal Combustion Engines, SAE Paper No.790501, (1979).

[2] Noguchi M., Tanaka T., Takeuchi,Y.: A Study on Gasoline Engine Combustion by Observation of Intermediate Reactive Products during Combustion, SAE Paper No. 790840, (1979).

[3] Najt P.M., Foster D.E.: Compression-Ignited Homogenous Charge Combustion, SAE Paper No. 830264, (1983).

[4] Thring R.H.: Homogenous Charge Compression-Ignition (HCCI) Engines, SAE Paper No. 892068, (1989).

[5] Ryan T.W., Callahan T.: Homogenous Charge Compression Ignition of Diesel Fuel, SAE Paper No. 961160, (1996).

[6] Fiveland S. B., Christensen M., Johansson B., Hiltner J., Mauss F., Assanis D.N.: Experimental and Simulated Results Detailing the Sensitivity of natural Gas HCCI Engines to Fuel Composition, SAE Paper No. 2001-01-3609, (2001).

[7] Stanglmaier R.H., Roberts C.E.: Homogenous Charge Compression Ignition (HCCI): Benefits, Compromises and Future Engine Applications, SAE Paper No. 1999-01-3682, (1999).

[8] Wang Z., Shuai S.J., Wang J.X., Tian G.H., An X.L.: Modeling of HCCI Combustion: From 0D to 3D, SAE Paper No.200601-1364, (2006).

[9] Hosseini V., Neill W.S., Checkel M.D.: Controlling N-Heptane HCCI Combustion with Partial Reforming: Experimental Results and Modeling Analysis, Proceeding of the ASME International Combustion Engine Division, Spring Technical Conference, ICES, 2008.

[10] Shahangian S. N., Keshavarz M., Javidrad G., Begheri N., Jazayeri S.A.: A Theoritical Study on Performance and Combustion Characteristics of HCCI Engine Operating with Diesel Surrogate Fuels: NHeptane, Dimethyl Ether, Proceeding of the ASME International Combustion Engine Division, Spring Technical Conference, ICES, 2008.

Mr. Jazayeri Seyed Ali - Assistant Professor in the Faculty of Mechanical Engineering at K. N . Toosi University of Technology.

Dr Jazayeri S. Ali jest docentem na Wydziale Mechanicznym Khajeh Nasir Toosi University of Technology w Teheranie, Iran. e-mail: jazayeri@kntu.ac.ir
[11] Orlandini I., Kulzer A., Weberbauer F., Rauscher M.: Simulation of Self Ignition in HCCI and Partial HCCI Engines Using a Reduced Order Model, SAE Paper No. 2005- 01-0159, (2005).

[12] Jeffrey M.G.: Numerical Modeling of Charge Stratification for the Combustion Control of HCCI Engines, SAE Paper No. 2005-01-3722, (2005).

[13] Gharabaghi S., Wilson T.S., Xu H., Cryan S., Richardson S., Wyszynski M.L., Misztal J.: Modeling and Experimental Investigations of Supercharged HCCI Engines, SAE Paper No. 2006-01-0634, (2006).

[14] Kongsereeparp P., Checkerl M.D.: Novel Method of Setting Initial Conditions for Multi-Zone HCCI Combustion Modeling, SAE Paper No. 2007-01-0674, (2007).

[15] www.me.berkeley.edu/gri_mech

[16] Kuo, Kenneth Kuan-Yun, Principles of Combustion, John Wiley \& Sons, Inc. , 1st Edition, 1986.

[17] homepages.vub.ac.be/ akonnov/science/mechanism/texts/ mech0_4.txt

[18] Heywood, John B., Internal Combustion Engine Fundamentals, McGraw-Hill Book Company, 1st Edition, 1988.

[19] Chang J., Guralp O., Filipi Z., Assanis D., Kuo T.W., Najt P., Rask R.: New Heat Transfer Correlation for an HCCI Engine Derived from Measurements of Instantaneous Surface Heat Flux, SAE Paper No. 2004-01-2996, (2004).

[20] Fiveland S.B., Assanis D.N.: Development and Validation of a Quasi-Dimensional Model for HCCI Engine Performance and Emissions Studies under Turbocharged Conditions, SAE Paper No. 2002-01-1757, (2002).

[21] Morsy M.H.: Ignition Control of Methane Fueled Homogenous Charge Compression Ignition Engines Using Additives, Fuel 86 (2007), pp 533-540, 2007.

[22] Aceves A.M., Flowers D.L., Westbook C.K., Smith J.R., Dibbe R.: A Multi-Zone Model for Prediction of HCCI Combustion and Emissions, SAE Paper No. 2000-01-0327, (2000).
Mr. Jahanian Omid, PhD. - Researcher in the Faculty of Mechanical Engineering at K.N. Toosi University of Technology.

Dr Jahanian Omid jest pracownikiem naukowym na Wydziale Mechanicznym Khajeh Nasir Toosi University of Technology w Teheranie, Iran.

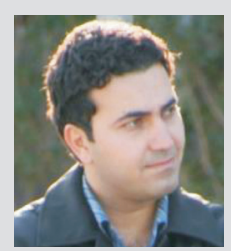

